ISSN 1678-3921

Journal homepage: www.embrapa.br/pab

For manuscript submission and journal contents, access: www.scielo.br/pab

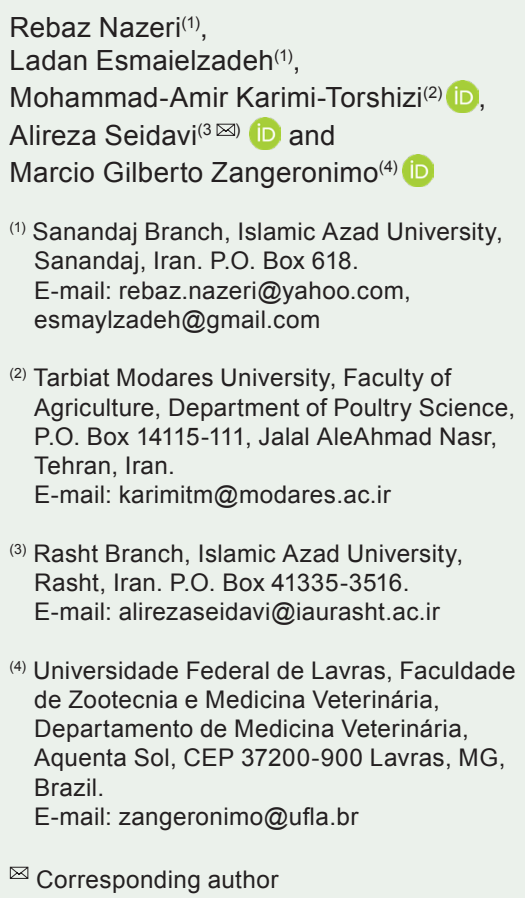

\section{Use of earthworm meal with vermi-humus in diet for laying quail}

\begin{abstract}
The objective of this work was to evaluate the effect of dietary earthworm (Eisenia fetida) meal (EW), associated with vermi-humus (VH), on the performance, egg characteristics, immunity, and blood constituents of laying quails. A total of 336 female quails ( $42.5 \pm 1.5 \mathrm{~g}$ ), with 30 days of age, was distributed in 7 treatments and 4 replicates of 12 birds during 42 days. The following treatments were evaluated: control diet without the inclusion of $\mathrm{VH}$ and EW; diet with the inclusion of only $0.8 \% \mathrm{VH}$; and diets with $0.8 \% \mathrm{VH}$ supplemented with different EW levels $(0.5,1.0,1.5,2.0$, and 2.5\%). A greater body weight, weight gain, and feed intake were obtained with $1.5 \% \mathrm{EW}$; a higher egg productivity, with $0.5-1.0 \% \mathrm{EW}$; and a higher egg mass, with $0.5 \%$ EW. The inclusion of $2.5 \% \mathrm{EW}$ reduced eggshell weight and thickness. Levels of $1.0-2.0 \% \mathrm{EW}$ decreased malondialdehyde in the eggs, whereas $2.0 \% \mathrm{EW}$ reduced cholesterol content. Higher blood cell volume and antibody titer were obtained with $1.0 \% \mathrm{EW}$, whereas higher total protein, globulin, and calcium were obtained with $0.5 \% \mathrm{EW}$. Levels of $1.0-1.5 \% \mathrm{EW}+0.8 \% \mathrm{VH}$ improve egg production and characteristics, as well as the humoral response of quails, whose performance is not affected.
\end{abstract}

Index terms: alternative feed, egg quality, humoral response, livestock, nutrition, poultry farming.

\section{Uso de farinha de minhoca com vermi-húmus em dieta para codornas de postura}

Resumo - O objetivo deste trabalho foi avaliar o efeito de farinha de minhoca (EW) (Eisenia fetida) dietética, associada ao vermi-húmus (VH), sobre o desempenho, as características dos ovos, a imunidade e os constituintes do sangue de codornas poedeiras. Um total de 336 codornas fêmeas $(42,5 \pm 1,5$ g), com 30 dias de idade, foi distribuído em 7 tratamentos e 4 repetições de 12 aves, por 42 dias. Foram avaliados os seguintes tratamentos: dieta controle sem a inclusão de VH e EW; dieta com inclusão somente de $0,8 \% \mathrm{VH}$; e dieta com $0,8 \% \mathrm{VH}$ suplementada com diferentes níveis de $\mathrm{EW}(0,5,1,0,1,5$, 2,0 e 2,5\%). Foram obtidos maiores peso vivo, ganho de peso e consumo de ração com $1,5 \%$ de EW; maior produção de ovos com $0,5-1,0 \%$ de EW; e maior massa de ovos com $0,5 \%$ de EW. A inclusão de $2,5 \%$ EW reduziu o peso e a espessura da casca do ovo. Níveis de 1,0-2,0\% de EW diminuíram o malonaldeído nos ovos, enquanto o de $2,0 \%$ de EW reduziu o conteúdo de colesterol. Foram obtidos maiores volume de células sanguíneas e título de anticorpos com $1,0 \%$ de $\mathrm{EW}$, enquanto maiores proteína total, globulina e cálcio foram obtidos com $0,5 \%$ de EW. Níveis de $1,0-1,5 \%+0,8 \%$ de $\mathrm{VH}$ melhoram a produção e as características dos ovos, bem como a resposta humoral das codornas, cujo desempenho não é afetado.

Termos para indexação: alimento alternativo, qualidade do ovo, resposta humoral, animais de criação, nutrição, avicultura. 


\section{Introduction}

Currently, one of the greatest challenges in animal production is to adapt diets to ensure maximum productivity with the lowest feed cost. In this sense, the inclusion of alternative foods that can replace corn and soybean meal are important. A potential alternative feedstuff is earthworm meal (EW) (Bahadori et al., 2017), whose greatest advantage is its efficiency in reproducing annelids in organic waste (Edwards, 1985), as well as its ease of being processed and stored (Rodriguez-Campos et al., 2014). Earthworms can be produced using fresh manure from cattle, swine, goat, and chicken, besides leaves, sawdust, rice hull, rice bran (Barcelo, 1988), and several fruit and vegetable wastes used as feedstock (Conti et al., 2019). Therefore, stimulating the adoption of this type of compost in animal feed is directly related to sustainability.

In their review paper, Parolini et al. (2020) found that EW contains a higher crude protein (CP) content in dry matter (DM) than soybean meal and fishmeal, as well as a lysine content similar to that of fishmeal, but with a lower digestible energy content. According to Bahadori et al. (2017), EW contains 91\% DM, 66\% CP in DM, 3,248 $\mathrm{kcal} \mathrm{kg}^{-1}$ metabolizable energy, $7.0 \%$ fat, a calcium:phosphorus ratio of $0.37,2.15 \%$ methionine + cystine, and 4.4\% lysine. Prayogi (2011) observed that increasing EW up to $10 \%$, as a replacement for fishmeal in diets, improved the performance of male quails. For laying hens, Son (2009) reported that the use of up to $0.6 \%$ dietary EW improved egg laying and quality, particularly the $\omega-6 / \omega-3$ fatty acid ratio in the egg yolk. Other authors also found positive effects when combining EW with vermi-humus (VH) (Bahadori et al., 2017; Hesami et al., 2020).

$\mathrm{VH}$ is a source of humic acid, which is formed from the decomposition of organic materials in the soil. This acid can be used as a food additive because it inhibits the growth of bacteria and fungi and also prevents the occurrence of high mycotoxin levels in the feed (Rezaeipour et al., 2014). Ozturk et al. (2012) concluded that $\mathrm{VH}$ can improve the performance, welfare, and immune system of broiler chicken, besides preventing intestinal diseases (Bahadori et al., 2017). Therefore, mixing EW, a feedstuff with a high crude protein level, and $\mathrm{VH}$, which can improve the profile of intestinal microbiota, can be interesting to improve animal performance and immune status. In fact, studies have already been carried out using these ingredients in diets for broilers (Bahadori et al., 2017) and breeding quails (Hesami et al., 2020). However, there are no known reports on the effect of these ingredients on the blood constitutes and egg quality of laying quails, which is important since the use of alternative protein sources could impair bird laying performance due to nutritional imbalances (Marono et al., 2017).

The objective of this work was to evaluate the effect of dietary EW, associated with $\mathrm{VH}$, on the performance, egg characteristics, immunity, and blood constituents of laying quails.

\section{Materials and Methods}

The experimental procedures were approved by the ethics committee of Islamic Azad University (protocol number 13940629). A total of 336 female Japanese quails (Coturnix japonica Temmink \& Schlegel, 1849), weighing $163.94 \pm 1.5 \mathrm{~g}$ and aged 30 days, were equally assigned to 28 cages $(0.2 \times 0.2 \mathrm{~m})$, positioned at the center of a thermostatically-controlled poultry barn with side-wall curtains, during 42 days. The cage floors were covered with wood shavings as bedding. Throughout the entire experimental period, ambient temperature was maintained at $22^{\circ} \mathrm{C}$ within the barn, using supplemental heat from thermostaticallycontrolled gasoline rocket heaters, and misting was used to maintain relative humidity at $70 \%$. The lighting program in the barn was: 20 lux, using $20 \mathrm{~W}$ fluorescent lamps in ceiling fixtures; and a photoperiod of 16 hours light:8 hours dark until the end of the experiment. The barn was tunnel ventilated, with air circulation being facilitated by fans mounted on the wall at one end of the barn. Quails had free access to the diets and clean fresh water during the entire experimental period.

A single-phase feeding program was used throughout the experiment. The chemical composition of the tested feedstuffs was determined (Table 1). The assessed treatments were: control diet, with $0 \% \mathrm{EW}$ and $0 \% \mathrm{VH}$; a diet containing $0.8 \% \mathrm{VH}$; and five diets containing $0.8 \% \mathrm{VH}$ supplemented with different EW levels $(0.5,1.0,1.5,2.0$, and 2.5\%) (Table 2). VH and EW are commercial products that were obtained from a local supplier (Amizeh Tabiat Co, Tehran, Iran). All diets were formulated to meet or exceed the recommendations for quails (NRC, 1994).

The experimental design was completely randomized, with 7 treatments and 4 replicates of 12 
birds each. The mean body weights of the quails were similar across the evaluated groups.

Body weight was measured on the first and last days of the experiment, whereas feed intake was determined throughout the entire experimental period. The eggs were manually collected, and their number and weight were recorded daily in each cage. Egg productivity (\%), ratio between number of produced eggs and feed, weight of produced eggs, ratio between weight of produced eggs and feed, and egg mass were calculated for each replicate during the experiment.

Four eggs of each replicate were collected at the end of the experimental period and were individually opened; yolks were separated from the albumen and then weighed. Shell thickness (with shell membrane) was measured, using a micrometer, at three locations on the eggs - air cell, equator, and sharp end. Eggshell weight (plus adhering membranes) was determined

Table 1. Chemical composition of the used earthworm (Eisenia fetida) meal and vermi-humus.

\begin{tabular}{lcc}
\hline Properties & Earthworm meal & Vermi-humus \\
\hline Dry matter (\%) & 91.0 & - \\
Crude protein (\%) & 65.68 & 7.27 \\
Crude fat (\%) & - & 0.14 \\
Metabolizable energy (kcal kg-1) & 3,258 & - \\
Crude fiber (\%) & 7.03 & - \\
Ash (\%) & - & 64.86 \\
Calcium (\%) & 0.45 & 8.97 \\
Phosphorus (\%) & 1.22 & 0.70 \\
Methionine (\%) & 1.20 & - \\
Cysteine (\%) & 0.95 & - \\
Methionine + cysteine (\%) & 2.15 & - \\
Lysine (\%) & 4.44 & - \\
Threonine (\%) & 2.99 & - \\
Arginine (\%) & 4.41 & - \\
Isoleucine (\%) & 2.95 & - \\
Leucine (\%) & 5.02 & - \\
Valine (\%) & 3.22 & - \\
Histidine & 1.74 & - \\
Phenylalanine (\%) & 2.72 & - \\
Glycine (\%) & 3.46 & - \\
Serine (\%) & 2.94 & - \\
Proline (\%) & 2.41 & - \\
Alanine (\%) & 3.44 & - \\
Asparagine (\%) & 6.54 & - \\
Glutamine (\%) & -76 & - \\
Humic acid (\%) & - & - \\
Fulvic acid (\%) & & - \\
\hline
\end{tabular}

after eggs were washed and dried. A tripod micrometer was used to measure albumen height, whereas yolk color was determined using an egg yolk color fan. Yolk malondialdehyde (MDA) and egg cholesterol were measured using the standard protocols of commercial laboratory kits (Pars Azmun Co., Tehran, Iran).

On day 58, one bird per replicate with a body weight close to the average of the pen was selected for blood collection. Blood samples (2.0 mL per bird) from the wing vein were collected into heparinized tubes. Two hours after collection, blood samples were centrifuged at $1,300 \times \mathrm{g}$, for $15 \mathrm{~min}$, at room temperature. Plasma was stored in microcentrifuge tubes at $-20^{\circ} \mathrm{C}$ until analysis, using specific kits for glucose, globulin, albumin, triglyceride, uric acid, calcium, and phosphorus (Pars Azmun Co., Tehran, Iran).

Quails were vaccinated against Newcastle and influenza. Both vaccines were administrated by eye drop at 49 days of age on 2 birds per replicate and 8 birds per treatment. The quails also received sheep red blood cell (SRBC) injections at 42 and 49 days of age. The humoral immune response of the birds was evaluated by collecting blood at 63 days of age, to determine antibody titers against Newcastle and influenza, and at 49 and 56 days of age, to determine the antibody titer against SRBCs. For the analyses, a hemagglutination assay was carried out in serum, based on Pourhossein et al. (2015).

Data were subjected to the analysis of variance (Anova) using the general linear model procedures of the SAS/STAT, version 9.2, software (SAS Institute Inc., Cary, NC, USA). The Duncan multiple range test was used for pairwise comparison between treatments if the result of Anova was significant $(\mathrm{p} \leq 0.05)$. Polynomial (linear) contrasts were used to examine rate responses due to increasing amounts of EW in the diet. When data were not normally distributed or when some of the required assumptions for the Anova were violated, data were transformed before the analysis, following the guidelines of Büchse et al. (2007). Results were significant if $\mathrm{p} \leq 0.05$.

\section{Results and Discussion}

Compared with the control, $0.8 \% \mathrm{VH}$ did not influence the performance of laying quails, which was also not affected by the inclusion of up to $1.0 \% \mathrm{EW}+$ $0.8 \% \mathrm{VH}$ in the diets. In addition, there was no influence of the use of EW on bird mortality and egg weight. 
Quails fed 1.5\% EW showed a greater body weight at 70 days of age, weight gain, and feed intake than those fed 2.0 and $2.5 \%$ EW (Table 3). However, no differences were observed regarding these variables when comparing the different levels of EW with the control treatment. With $0.5 \% \mathrm{EW}$, egg production and mass were similar but slightly greater than those of the control, when compared with the higher inclusion levels. Moreover, the use of 1.5 and $2.5 \%$ EW increased the feed conversion of the quails.

The obtained results are indicative that low levels - between 0.5 and $1.0 \%$ - of EW, associated with $\mathrm{VH}$, should be used in laying quail diets in order to not decrease egg production. This result

Table 2. Ingredients and chemical composition of the experimental diets with different amounts of earthworm (Eisenia fetida) meal (EW) and vermi-humus (VH).

\begin{tabular}{|c|c|c|c|c|c|c|c|}
\hline \multirow[t]{2}{*}{ Ingredient $(\%)$} & \multicolumn{7}{|c|}{ Experimental diet } \\
\hline & Control & $\begin{array}{c}0.0 \mathrm{EW}+ \\
0.8 \mathrm{VH}\end{array}$ & $\begin{array}{c}0.5 \mathrm{EW}+ \\
0.8 \mathrm{VH}\end{array}$ & $\begin{array}{c}1.0 \mathrm{EW}+ \\
0.8 \mathrm{VH}\end{array}$ & $\begin{array}{c}1.5 \mathrm{EW}+ \\
0.8 \mathrm{VH}\end{array}$ & $\begin{array}{c}2.0 \mathrm{EW}+ \\
0.8 \mathrm{VH}\end{array}$ & $\begin{array}{c}2.5 \mathrm{EW}+ \\
0.8 \mathrm{VH}\end{array}$ \\
\hline Corn & 50.48 & 49.74 & 49.07 & 48.64 & 48.12 & 47.62 & 47.91 \\
\hline Soybean oil & 1.92 & 1.89 & 2.17 & 2.15 & 2.14 & 2.14 & 2.14 \\
\hline Soybean meal 44\% & 32.36 & 32.41 & 32.50 & 32.54 & 32.59 & 32.64 & 32.68 \\
\hline DL-methionine $99 \%$ & 0.29 & 0.28 & 0.28 & 0.27 & 0.26 & 0.25 & 0.24 \\
\hline L-lysine-hydrochloride $99 \%$ & 0.06 & 0.03 & 0.03 & 0.00 & 0.00 & 0.00 & 0.00 \\
\hline Meat meal 55\% & 7.00 & 7.00 & 7.00 & 7.00 & 7.00 & 7.00 & 7.00 \\
\hline Sodium bicarbonate & 0.14 & 0.12 & 0.12 & 0.09 & 0.10 & 0.09 & 0.09 \\
\hline Dicalcium phosphate & 0.19 & 0.17 & 0.14 & 0.12 & 0.10 & 0.08 & 0.06 \\
\hline Calcium carbonate & 6.89 & 6.88 & 6.71 & 6.70 & 6.70 & 6.69 & 6.69 \\
\hline Sodium chloride & 0.17 & 0.18 & 0.18 & 0.19 & 0.19 & 0.19 & 0.19 \\
\hline Vitamin/mineral premix ${ }^{(1)}$ & 0.25 & 0.25 & 0.25 & 0.25 & 0.25 & 0.25 & 0.25 \\
\hline Earthworm $^{(2)}$ & 0.00 & 0.00 & 0.50 & 1.00 & 1.50 & 2.00 & 2.50 \\
\hline Vermi-humus & 0.00 & 0.80 & 0.80 & 0.80 & 0.80 & 0.80 & 0.80 \\
\hline \multicolumn{8}{|l|}{ Nutrient calculated } \\
\hline Metabolizable energy $\left(\mathrm{kcal} \mathrm{kg}^{-1}\right)$ & 2,800 & 2,800 & 2,800 & 2,800 & 2,800 & 2,800 & 2,800 \\
\hline Crude protein (\%) & 22.20 & 22.51 & 22.53 & 22.84 & 23.15 & 23.46 & 23.77 \\
\hline Lysine $(\%)$ & 1.23 & 1.20 & 1.24 & 1.18 & 1.18 & 1.18 & 1.18 \\
\hline Methionine (\%) & 0.61 & 0.61 & 0.61 & 0.60 & 0.59 & 0.58 & 0.57 \\
\hline Methionine + cystine $(\%)$ & 0.98 & 0.97 & 0.96 & 0.96 & 0.96 & 0.93 & 0.92 \\
\hline Threonine (\%) & 0.84 & 0.84 & 0.84 & 0.84 & 0.84 & 0.72 & 0.66 \\
\hline Tryptophan (\%) & 0.23 & 0.23 & 0.22 & 0.21 & 0.21 & 0.22 & 0.20 \\
\hline Arginine (\%) & 1.38 & 1.38 & 1.37 & 1.36 & 1.38 & 1.27 & 0.18 \\
\hline Isoleucine (\%) & 0.91 & 0.91 & 0.91 & 0.91 & 0.92 & 0.77 & 0.72 \\
\hline Valine (\%) & 1.00 & 1.00 & 1.00 & 1.01 & 1.02 & 0.85 & 0.80 \\
\hline Leucine (\%) & 2.17 & 2.17 & 2.17 & 2.18 & 2.20 & 1.59 & 1.51 \\
\hline Calcium (\%) & 3.10 & 3.10 & 3.10 & 3.10 & 3.10 & 3.10 & 3.10 \\
\hline Available phosphorus (\%) & 0.32 & 0.32 & 0.32 & 0.32 & 0.32 & 0.32 & 0.32 \\
\hline Sodium (\%) & 0.16 & 0.16 & 0.16 & 0.16 & 0.16 & 0.16 & 0.16 \\
\hline Potassium (\%) & 0.88 & 0.89 & 0.87 & 0.86 & 0.86 & 0.86 & 0.81 \\
\hline Chloride (\%) & 0.18 & 0.18 & 0.18 & 0.18 & 0.18 & 0.29 & 0.28 \\
\hline $\left.\operatorname{DCAB}(\mathrm{mEq} \mathrm{kg})^{-1}\right)^{(3)}$ & 244 & 244 & 234 & 225 & 219 & 209 & 198 \\
\hline Linoleic acid (\%) & 1.34 & 1.31 & 1.32 & 1.34 & 1.33 & 1.39 & 1.41 \\
\hline Ether extract (\%) & 3.43 & 3.75 & 3.42 & 3.08 & 2.87 & 4.63 & 5.69 \\
\hline Crude fiber (\%) & 3.62 & 3.61 & 3.51 & 3.40 & 3.35 & 3.55 & 3.37 \\
\hline
\end{tabular}

(1)Provided per kilogram of feed: 3,600,000 IU vitamin A; 800,000 IU vitamin D3; $7.2 \mathrm{~g}$ vitamin E; $0.8 \mathrm{~g}$ vitamin K3; $0.7 \mathrm{~g}$ thiamine; $2.64 \mathrm{~g}$ riboflavin; $4.0 \mathrm{~g}$ niacin; $3.92 \mathrm{~g}$ calcium pantothenate; $1.176 \mathrm{~g}$ pyridoxine; $0.4 \mathrm{~g}$ folic acid; $6.0 \mathrm{mg}$ vitamin $\mathrm{B}_{12} ; 40 \mathrm{mg}$ biotin; $100 \mathrm{mg}$ choline chloride; $40 \mathrm{mg}$ manganese; $20 \mathrm{mg}$ iron; $33.88 \mathrm{mg}$ zinc; $4.0 \mathrm{mg}$ copper; $0.4 \mathrm{mg}$ iodine; and $0.08 \mathrm{mg}$ selenium. ${ }^{(2)}$ Obtained from Amize Tabiat Co., a local supplier, located in Tehran, Iran. ${ }^{(3)}$ Dietary cation-anion balance. 
was similar to those found by Hesami et al. (2020), who recommended levels between 1.0 and $1.5 \%$ for Japanese breeder quails.

In the literature, the effects of EW on bird feed intake and weight gain vary. Prayogi (2011) and Struti et al. (2018) observed a higher weight gain when using $10 \%$ earthworm meal in quail diets. For broilers, Zang et al. (2018) found a greater weight gain and feed intake when using 3.0 and 5.0\% earthworm powder. However, Bahadori et al. (2017) reported a decrease in the growth performance of broiler chickens with an increasing amount of EW up to $3.0 \%$ in dry matter. These results can be attributed to the different characteristics of the used EW, such as age of the annelids and ways of processing the feedstuff.

Regarding $\mathrm{VH}$, there are reports that this food increases the growth of broilers (Ozturk et al., 2012; Jad'uttová et al., 2019). However, in the present study, the diet containing only $\mathrm{VH}$ did not influence quail performance, probably because the tested amount was too low to affect the studied variables. These results are similar to those found by Nagaraju et al. (2014) when testing $0.05,0.075$, and $0.1 \%$ humic acid.

In the present study, the feed intake of the experimental diets by the birds did not differ from that of the control, and the crude protein content of the diets varied between 22.2 and $23.8 \%$ (Table 2). Regarding EW, only low levels (1.0\%) did not impair the productive performance of the birds. The inclusion of up to $2.5 \%$ EW reduced the amount of arginine in $87 \%$, leucine in $30 \%$, and threonine, valine, and isoleucine in $20 \%$ (Table 2). This suggests that, for the use of higher EW levels, it may be necessary to supplement the diet with other amino acids, in addition to lysine and methionine, following the ideal protein concept in the formulation of diets (Emmert \& Baker, 1997). This is important since the inclusion of alternative foods in farm animal diets can cause a nutritional imbalance, especially of amino acids.

The inclusion of EW $+\mathrm{VH}$ reduced linearly albumen height, eggshell weight, and egg MDA concentration and cholesterol (Table 4). Moreover, compared with the control, the inclusion of $2.5 \% \mathrm{EW}+$ $0.8 \% \mathrm{VH}$ reduced eggshell thickness and weight. The inclusion of $1.0-2.0 \% \mathrm{EW}+0.8 \% \mathrm{VH}$ reduced MDA concentration in eggs, while that of $2.0 \% \mathrm{EW}$ reduced cholesterol content. However, there was no effect of the tested feedstuffs on the weight and color of the yolk, although the inclusion of high amounts of EW impaired the physical quality of the eggs. This result is probably related to the nutritional imbalance caused by the high inclusion of this meal. According to Kaur et al. (2008), the wide variation in the composition and amount of protein and/or energy present in feedstuffs can influence bird performance.

The lack of changes in yolk color due to the evaluated diets was expected since there was no detectable presence of carotenoids in EW or $\mathrm{VH}$ and the reduction in corn meal was not significant. Franco \& Sakamoto (2012) concluded that yolk color can vary

Table 3. Effect of different dietary amounts of earthworm meal (Eisenia fetida) (EW) and vermi-humus (VH) on the performance of laying quails from 30 to 72 days of age ${ }^{(1)}$.

\begin{tabular}{|c|c|c|c|c|c|c|c|c|c|c|}
\hline Parameter & Control & $\begin{array}{r}0.0 \mathrm{EW}+ \\
0.8 \mathrm{VH}\end{array}$ & $\begin{array}{r}0.5 \mathrm{EW}+ \\
0.8 \mathrm{VH}\end{array}$ & $\begin{array}{r}1.0 \mathrm{EW}+ \\
0.8 \mathrm{VH}\end{array}$ & $\begin{array}{r}1.5 \mathrm{EW}+ \\
0.8 \mathrm{VH}\end{array}$ & $\begin{array}{r}2.0 \mathrm{EW}+ \\
0.8 \mathrm{VH}\end{array}$ & $\begin{array}{r}2.5 \mathrm{EW}+ \\
0.8 \mathrm{VH}\end{array}$ & $\mathrm{SEM}^{(2)}$ & p-value & Linear $^{(3)}$ \\
\hline Mortality (\%) & 0.44 & 0.22 & 1.16 & 0.45 & 0.22 & 0.44 & 0.00 & 0.51 & 0.10 & 0.19 \\
\hline Body weight at 30 days of age $(\mathrm{g})$ & 164.16 & 164.75 & 161.50 & 164.75 & 163.75 & 163.51 & 165.16 & 3.35 & 0.79 & 0.75 \\
\hline Body weight at 70 days of age $(\mathrm{g})$ & $212 \mathrm{ab}$ & $211 \mathrm{ab}$ & $211 \mathrm{ab}$ & $208 \mathrm{abc}$ & $216 \mathrm{a}$ & $202 \mathrm{c}$ & $206 b c$ & 3.83 & $<0.01$ & 0.01 \\
\hline Weight gain (g per day) & $48.48 \mathrm{ab}$ & $46.50 \mathrm{ab}$ & $49.50 \mathrm{ab}$ & $43.25 \mathrm{ab}$ & $52.50 \mathrm{a}$ & $39.09 \mathrm{~b}$ & $41.75 b$ & 5.52 & 0.03 & 0.75 \\
\hline Feed intake ( $\mathrm{g}$ per day) & $25.50 \mathrm{ab}$ & $24.75 b$ & $25.50 \mathrm{ab}$ & $27.07 \mathrm{a}$ & $27.25 \mathrm{a}$ & $25.05 b$ & $24.50 \mathrm{~b}$ & 0.83 & $<0.01$ & 0.73 \\
\hline Egg productivity (\%) & $42.86 \mathrm{ab}$ & $38.25 \mathrm{ab}$ & $48.16 \mathrm{a}$ & $45.50 \mathrm{a}$ & $29.37 b$ & $39.23 \mathrm{ab}$ & $30.38 b$ & 6.20 & $<0.01$ & $<0.01$ \\
\hline Egg weight (g) & 11.86 & 11.54 & 11.97 & 11.32 & 11.72 & 11.74 & 10.78 & 0.70 & 0.05 & 0.11 \\
\hline Egg mass $(\mathrm{g})$ & $5.08 \mathrm{ab}$ & $4.40 \mathrm{abc}$ & $5.79 \mathrm{a}$ & $5.09 \mathrm{ab}$ & $3.46 \mathrm{bc}$ & $4.62 \mathrm{abc}$ & $3.27 \mathrm{c}$ & 0.76 & $<0.01$ & $<0.01$ \\
\hline Feed conversion ratio & $3.09 b$ & $3.37 \mathrm{~b}$ & $3.01 \mathrm{~b}$ & $3.34 \mathrm{~b}$ & $4.81 \mathrm{a}$ & $3.33 b$ & $4.38 \mathrm{a}$ & 0.44 & $<0.01$ & $<0.01$ \\
\hline
\end{tabular}

${ }^{(1)}$ Means followed by different letters, in the lines, differ significantly by Duncan's test, at $0.05 \%$ probability. $n=4$. (2) Standard error of the mean. ${ }^{(3)}$ Probability of a linear response to increasing levels of earthworm meal in the diet. The treatments were: control, basal diet without the inclusion of EW or $\mathrm{VH}(0 \mathrm{EW}+0 \mathrm{VH})$; and diets containing $0.8 \% \mathrm{VH}(0.8 \mathrm{VH})$ supplemented with $0,0.5,1.0,1.5,2.0$, and $2.5 \% \mathrm{EW}(0 \mathrm{EW}, 0.5 \mathrm{EW}, 1.0 \mathrm{EW}, 1.5 \mathrm{EW}, 2.0$ $\mathrm{EW}$, and $2.5 \mathrm{EW}$, respectively). 
from pale yellow to dark orange depending on the amount of carotenoids present in the bird diet.

The concentration of lipids increased from $3.43 \%$ in the control diet to $5.69 \%$ with the highest level of EW (Table 2). However, triglyceride levels in quail blood did not differ (Table 5), despite the decrease in the cholesterol in the eggs of the birds fed diets with high EW levels (Table 4). Likewise, Bahadori et al. (2017) observed that broiler chickens fed higher amounts of EW and $\mathrm{VH}$ had a lower blood cholesterol.
Other authors also found that the decrease in blood cholesterol in broiler chickens is one of the effects of humic substances such as VH (Ozturk et al., 2012; Jad'uttová et al., 2019). However, since egg cholesterol is important for embryo and post-hatching development (Sutton et al., 1984), the use of higher EW levels in breeding needs to be better evaluated.

In the present work, the reduction of cholesterol in the eggs was accompanied by a reduction in MDA concentration. However, the increase in the amount of

Table 4. Effect of different dietary amounts of earthworm (Eisenia fetida) meal (EW) and vermi-humus (VH) on the egg quality of laying quails from 30 to 72 days of age ${ }^{(1)}$.

\begin{tabular}{lcccccccccc}
\hline Parameter & Control & $\begin{array}{c}0.0 \mathrm{EW}+ \\
0.8 \mathrm{VH}\end{array}$ & $\begin{array}{c}0.5 \mathrm{EW}+ \\
0.8 \mathrm{VH}\end{array}$ & $\begin{array}{c}1.0 \mathrm{EW}+ \\
0.8 \mathrm{VH}\end{array}$ & $\begin{array}{c}1.5 \mathrm{EW}+ \\
0.8 \mathrm{VH}\end{array}$ & $\begin{array}{c}2.0 \mathrm{EW}+ \\
0.8 \mathrm{VH}\end{array}$ & $\begin{array}{c}2.5 \mathrm{EW}+ \\
0.8 \mathrm{VH}\end{array}$ & SEM $^{(2)}$ & $\mathrm{p}^{-v^{2}}$ & Linear $^{(3)}$ \\
\hline Shell thickness $\left(\mathrm{mm} \times 10^{-2}\right)$ & $0.220 \mathrm{ab}$ & $0.220 \mathrm{ab}$ & $0.221 \mathrm{ab}$ & $0.229 \mathrm{a}$ & $0.222 \mathrm{ab}$ & $0.224 \mathrm{ab}$ & $0.212 \mathrm{~b}$ & 0.010 & 0.03 & 0.37 \\
Albumen height $(\mathrm{mm})$ & 4.58 & 4.49 & 4.78 & 4.61 & 4.53 & 3.96 & 4.23 & 0.703 & 0.11 & 0.03 \\
Yolk weight $(\mathrm{g})$ & 4.39 & 4.38 & 4.39 & 4.57 & 4.52 & 4.50 & 4.28 & 0.58 & 0.91 & 0.94 \\
Shell weight $(\mathrm{g})$ & $1.04 \mathrm{a}$ & $1.07 \mathrm{a}$ & $1.05 \mathrm{a}$ & $1.01 \mathrm{ab}$ & $1.05 \mathrm{a}$ & $1.09 \mathrm{a}$ & $0.91 \mathrm{~b}$ & 0.11 & $<0.01$ & 0.04 \\
Yolk color & 6.41 & 6.08 & 6.08 & 5.41 & 5.33 & 5.16 & 6.08 & 1.39 & 0.22 & 0.10 \\
Malondialdehyde $\left(\mu \mathrm{g} \mathrm{g}^{-1}\right)$ & $1.14 \mathrm{a}$ & $0.62 \mathrm{ab}$ & $0.59 \mathrm{ab}$ & $0.50 \mathrm{~b}$ & $0.46 \mathrm{~b}$ & $0.50 \mathrm{~b}$ & $0.60 \mathrm{ab}$ & 0.21 & 0.02 & 0.01 \\
Cholesterol $\left(\mathrm{mg} \mathrm{dL}^{-1}\right)$ & $216.39 \mathrm{a}$ & $168.36 \mathrm{ab}$ & $214.75 \mathrm{a}$ & $165.98 \mathrm{ab}$ & $187.04 \mathrm{ab}$ & $150.40 \mathrm{~b}$ & $182.62 \mathrm{ab}$ & 28.11 & 0.02 & 0.03 \\
\hline
\end{tabular}

${ }^{(1)}$ Means followed by different letters, in the lines, differ significantly by Duncan's test, at $0.05 \%$ probability. $n=4$. ${ }^{(2)}$ Standard error of the mean . (3) Probability of a linear response to increasing levels of earthworm meal in the diet. The treatments were: control, a basal diet without the inclusion of $\mathrm{EW}$ or $\mathrm{VH}(0 \mathrm{EW}+0 \mathrm{VH})$; and diets containing $0.8 \% \mathrm{VH}(0.8 \mathrm{VH})$ supplemented with $0,0.5,1.0,1.5,2.0$, and $2.5 \% \mathrm{EW}(0 \mathrm{EW}, 0.5 \mathrm{EW}, 1.0 \mathrm{EW}, 1.5 \mathrm{EW}$, $2.0 \mathrm{EW}$, and $2.5 \mathrm{EW}$, respectively).

Table 5. Effect of different dietary amounts of earthworm (Eisenia fetida) meal (EW) and vermi-humus (VH) on the blood constituents of laying quails from 30 to 72 days of age ${ }^{(1)}$.

\begin{tabular}{|c|c|c|c|c|c|c|c|c|c|c|}
\hline Constituent & Control & $\begin{array}{c}0.0 \mathrm{EW}+ \\
0.8 \mathrm{VH} \\
\end{array}$ & $\begin{array}{c}0.5 \mathrm{EW}+ \\
0.8 \mathrm{VH}\end{array}$ & $\begin{array}{c}1.0 \mathrm{EW}+ \\
0.8 \mathrm{VH}\end{array}$ & $\begin{array}{c}1.5 \mathrm{EW}+ \\
0.8 \mathrm{VH}\end{array}$ & $\begin{array}{c}2.0 \mathrm{EW}+ \\
0.8 \mathrm{VH}\end{array}$ & $\begin{array}{c}2.5 \mathrm{EW}+ \\
0.8 \mathrm{VH}\end{array}$ & $\mathrm{SEM}^{(2)}$ & p-value & Linear $^{(3)}$ \\
\hline Mean blood cell volume & $39.75 \mathrm{ab}$ & $40.75 \mathrm{ab}$ & $45.0 \mathrm{a}$ & $37.5 b$ & $44.0 \mathrm{a}$ & $39.5 \mathrm{ab}$ & $42.25 \mathrm{ab}$ & 2.62 & $<0.01$ & 0.57 \\
\hline Total protein $\left(\mathrm{mg} \mathrm{dl}^{-1}\right)$ & $5.12 \mathrm{bc}$ & $4.96 \mathrm{c}$ & $5.90 \mathrm{a}$ & $5.34 \mathrm{bc}$ & $5.07 \mathrm{bc}$ & $5.43 \mathrm{abc}$ & $5.51 \mathrm{ab}$ & 0.23 & $<0.01$ & 0.05 \\
\hline Glucose (mg dl-1 $)$ & 165.2 & 164.5 & 169.8 & 145.9 & 149.6 & 142.7 & 153.1 & 15.5 & 0.13 & 0.02 \\
\hline Globulin (mg dl-1 $)$ & $1.92 \mathrm{bc}$ & $1.68 \mathrm{c}$ & $2.50 \mathrm{a}$ & $2.12 \mathrm{ab}$ & $2.04 \mathrm{bc}$ & $2.20 \mathrm{ab}$ & $2.44 \mathrm{a}$ & 0.18 & $<0.01$ & $<0.01$ \\
\hline Albumin $\left(\mathrm{g} \mathrm{dl}^{-1}\right)$ & 3.19 & 3.28 & 3.39 & 3.21 & 3.03 & 3.23 & 3.07 & 0.20 & 0.23 & 0.12 \\
\hline Triglyceride $\left(\mathrm{mg} \mathrm{dl}^{-1}\right)$ & 290.7 & 254.1 & 292.2 & 292.4 & 201.3 & 205.7 & 312.3 & 81.5 & 0.33 & 0.57 \\
\hline Uric acid $\left(\mathrm{mg} \mathrm{dl}^{-1}\right)$ & 5.97 & 5.51 & 6.43 & 5.86 & 5.64 & 5.54 & 6.75 & 0.61 & 0.06 & 0.33 \\
\hline Calcium (mg dl-1 $)$ & $8.77 \mathrm{~b}$ & $9.31 \mathrm{ab}$ & $10.73 a$ & $10.16 \mathrm{ab}$ & $9.54 \mathrm{ab}$ & $9.29 \mathrm{ab}$ & $10.09 \mathrm{ab}$ & 0.74 & 0.02 & 0.17 \\
\hline Phosphorus (mg dl ${ }^{-1}$ ) & $5.46 \mathrm{ab}$ & $5.72 \mathrm{ab}$ & $4.58 \mathrm{ab}$ & $6.13 \mathrm{a}$ & $4.77 \mathrm{ab}$ & $4.19 \mathrm{~b}$ & $4.42 \mathrm{ab}$ & 0.84 & 0.02 & 0.01 \\
\hline \multicolumn{11}{|c|}{ Humoral immunity (antibody titer) $\left(\times \log _{2}\right)$} \\
\hline Anti-Newcastle & 0.25 & 1.50 & 0.75 & 0.75 & 0.50 & 1.00 & 0.75 & 0.95 & 0.66 & 0.92 \\
\hline Anti-influenza & $0.00 \mathrm{c}$ & $0.00 \mathrm{c}$ & $1.25 \mathrm{ab}$ & $1.63 \mathrm{a}$ & $1.25 b$ & $0.95 \mathrm{ab}$ & $1.57 \mathrm{a}$ & 1.01 & $<0.01$ & $<0.01$ \\
\hline Anti-sheep red blood cell & $0.75 \mathrm{c}$ & $2.00 \mathrm{~b}$ & $0.75 \mathrm{c}$ & $1.75 b c$ & $1.50 \mathrm{bc}$ & $3.00 \mathrm{a}$ & $3.00 \mathrm{a}$ & 1.13 & 0.04 & $<0.01$ \\
\hline
\end{tabular}

${ }^{(1)}$ Means followed by different letters, in the lines, differ significantly by Duncan's test, at $0.05 \%$ probability. $n=4$. (2) Standard error of the mean . ${ }^{(3)}$ Probability of a linear response to increasing levels of earthworm meal in the diet. The treatments were: control, a basal diet without the inclusion of $\mathrm{EW}$ or $\mathrm{VH}(0 \mathrm{EW}+0 \mathrm{VH})$; and diets containing $0.8 \% \mathrm{VH}(0.8 \mathrm{VH})$ supplemented with $0,0.5,1.0,1.5,2.0$, and $2.5 \% \mathrm{EW}(0 \mathrm{EW}, 0.5 \mathrm{EW}, 1.0 \mathrm{EW}, 1.5 \mathrm{EW}$, $2.0 \mathrm{EW}$, and $2.5 \mathrm{EW}$, respectively). 
lipids in the diet (Table 2), associated with a reduction in egg cholesterol (Table 4), suggests a lower lipid content in the eggs. In this case, further studies should be conducted with EW and VH to investigate the effects of these feedstuffs on the lipid metabolism of birds.

The inclusion of $\mathrm{EW}+\mathrm{VH}$ increased linearly the concentrations of total protein, globulin, and phosphorus in quail blood. Both phosphorus and calcium are essential elements for the structure and metabolism of bones and eggshells (NRC, 1994). However, higher levels of EW decreased the performance of laying quails and reduced the thickness and weight of the eggshells. According to DeLuca (1979), a lower level of blood phosphorus may indicate an imbalance in the calcium:phosphorus ratio of the diet due to phosphorus deficiency, which activates vitamin D, increasing the levels of blood calcium. Although the calcium:phosphorus ratio was corrected in all experimental diets in the present study, the effect of $\mathrm{EW}+\mathrm{VH}$ on calcium and phosphorus metabolism needs to be further clarified.

The inclusion of $\mathrm{EW}+\mathrm{VH}$ also reduced linearly glucose concentration and increased the antibody titers against influenza and SRBCs; however, there was no effect on the antibody titer against Newcastle. The inclusion of $0.5 \% \mathrm{EW}+0.8 \% \mathrm{VH}$ increased the concentrations of total protein, globulin, and calcium, as well as the antibody titer against influenza. The use of $0.8 \% \mathrm{VH}$ increased the antibody titer against SRBCs, except when associated with $0.5 \%$ EW. However, there was no effect of EW + VH inclusion on the concentrations of albumin, triglyceride, and uric acid in quail blood.

Similarly, Bahadori et al. (2017) found that the response of the antibodies of avian influenza was affected by EW supplementation, suggesting that this feedstuff may influence the systemic or humoral immunity of birds. In fact, the humoral components of EW include antimicrobial peptides, lectins, phenoloxidases, proteases, and pore-forming proteins (Popović et al., 2005). According to Cooper et al. (2002), specific molecules in the immune system of earthworms may be used as a natural antibiotic. Humic acid has immune-stimulatory, anti-inflammatory, and antiviral properties (Klocking, 1994). These mechanisms are probably related to the ability of this food to modify the intestinal microbiota (Bahadori et al., 2017). In this scenario, the benefits of using EW $+\mathrm{VH}$ at low levels go beyond egg quality and may even improve the health status of animals.

\section{Conclusion}

Earthworm meal (EW) and vermi-humus reduce the weight gain, production, and egg mass of quails, but low levels of $0.5 \% \mathrm{EW}$ do not impair egg production and mass.

\section{Acknowledgments}

To Islamic Azad University, for grant (number 17.16.4.18418); and to Conselho Nacional de Desenvolvimento Científico e Tecnológico (CNPq process number 303851/2019-8) and to Tarbiat Modares University, Amize Tabiat Co., and Dr Nezami, for support.

\section{References}

BAHADORI, Z.; ESMAIELZADEH, L.; KARIMI-TORSHIZI, M.A.; SEIDAVI, A.; OLIVARES, J.; ROJAS, S.; SALEM, A.Z.M.; KHUSRO, A.; LÓPEZ, S. The effect of earthworm (Eisenia foetida) meal with vermi-humus on growth performance, hematology, immunity, intestinal microbiota, carcass characteristics, and meat quality of broiler chickens. Livestock Science, v.202, p.74-81, 2017. DOI: https://doi.org/10.1016/j.livsci.2017.05.010.

BARCELO, P.M. Production and utilization of earthworms as feeds for broilers in the Philippines. Tropicultura, v.6, p.21-24, 1988.

BÜCHSE, A.; KRAJEWSKI, P.; KRISTENSEN, K.; PILARCZYK, W. Trial setup and statistical analysis. In: DONNER, D.; OSMAN, A. (Ed.). Handbook cereal variety testing for organic and low input agriculture. Wagening: COST860-SUSVAR, 2007. p.TSA1-TSA27.

CONTI, C.; BACENETTI, J.; TEDESCO, D. Earthworms for feed production from vegetable waste: environmental impact assessment. Environmental Engineering \& Management Journal, v.18, p.2117-2122, 2019.

COOPER, E.L.; KAUSCHKE, E.; COSSARIZZA, A. Digging for innate immunity since Darwin and Metchnikoff. BioEssays, v.24, p.319-333, 2002. DOI: https://doi.org/10.1002/bies.10077.

DELUCA, H.F. The vitamin D system in the regulation of calcium and phosphorus metabolism. Nutrition Reviews, v.37, p.161-193, 1979. DOI: https://doi.org/10.1111/j.1753-4887.1979.tb06660.x.

EDWARDS, C.A. Production of feed protein from animal waste by earthworms. Philosophical Transactions of the Royal Society B: Biological Sciences, v.310, p.299-307, 1985. DOI: https://oi.org/10.1098/rstb.1985.0120.

EMMERT, J.L.; BAKER, D.H. Use of the ideal protein concept 
for precision formulation of amino acid levels in broiler diets. Journal of Applied Poultry Research, v.6, p.462-470, 1997. DOI: https://doi.org/10.1093/japr/6.4.462.

FRANCO, J.R.G.; SAKAMOTO, M.I. Qualidade dos ovos: uma visão geral dos fatores que a influenciam. 2012. Available at: <https://pt.engormix.com/avicultura/artigos/qualidade-ovosgenetica-ambiente-nutricao-t37478.htm $>$. Accessed on: Dec. 3 2021.

HESAMI, Y.; ESMAIELZADEH, L.; KARIMI-TORSHIZI, M.A.; SEIDAVI, A.; VLCKOVÁ, R. Effect of diets containing earthworm powder and vermihumus on egg production, hatchability, blood parameters and immunity of Japanese breeder quails. Journal of Animal Physiology and Animal Nutrition, v.105, p.316-325, 2020. DOI: https://doi.org/10.1111/jpn.13453.

JAD'UTTOVÁ, I.; MARCINČÁKOVÁ, D.; BARTKOVSKÝ, M.; SEMJON, B.; HARČÁROVÁ, M.; NAGYOVÁ, A.; VÁCZI, P.; MARCINČÁK, S. The effect of dietary humic substances on the fattening performance, carcass yield, blood biochemistry parameters and bone mineral profile of broiler chickens. Acta Veterinaria Brno, v.88, p.307-313, 2019. DOI: https://doi.org/10.2754/avb201988030307.

KAUR, S.; MANDAL, A.B.; SINGH, K.B.; KADAM, M.M. The response of Japanese quails (heavy body weight line) to dietary energy levels and graded essential amino acid levels on growth performance and immuno-competence. Livestock Science, v.117, p.255-262, 2008. DOI: https://doi.org/10.1016/j.livsci.2007.12.019.

KLOCKING, R. Humic substances as potential therapeutics. In: SENESI, N.; MIANO, T.M. (Ed.). Humic substances in the global environment and implications on human health: proceedings of the $6^{\text {th }}$ International Meeting of the International Humic Substances Society, Monopoli (Bari), Italy, September 2025, 1992. Amsterdam: Elsevier, 1994. p.1245-1257.

MARONO, S.; LOPONTE, R.; LOMBARDI, P.; VASSALOTTI, G.; PERO, M.E.; RUSSO, F.; GASCO, L.; PARISI, G.; PICCOLO, G.; NIZZA, S.; DI MEO, C.; ATTIA, Y.A.; BOVERA, F. Productive performance and blood profiles of laying hens fed Hermetia illucens larvae meal as total replacement of soybean meal from 24 to 45 weeks of age. Poultry Science, v.96, p.17831790, 2017. DOI: https://doi.org/10.3382/ps/pew461.

NAGARAJU, R.; REDDY, B.S.V.; GLORIDOSS, R.; SURESH, B.; RAMESH, C. Effect of dietary supplementation of humic acids on performance of broilers. Indian Journal of Animal Sciences, v.84, p.447-452, 2014.

NRC. National Research Council. Nutrient requirements of poultry. $9^{\text {th }}$ ed. Washington: National Academies Press, 1994. $176 \mathrm{p}$.

OZTURK, E.; OCAK, N.; TURAN, A.; ERENER, G.; ALTOP, A.; CANKAYA, S. Performance, carcass, gastrointestinal tract and meat quality traits, and selected blood parameters of broilers fed diets supplemented with humic substances. Journal of the Science of Food and Agriculture, v.92, p.59-65, 2012. DOI: https://doi.org/10.1002/jsfa.4541

PAROLINI, M.; GANZAROLI, A.; BACENETTI, J. Earthworm as an alternative protein source in poultry and fish farming: current applications and future perspectives. Science of the Total Environment, v.734, art.139460, 2020. DOI: https://doi.org/10.1016/j.scitotenv.2020.139460.

POPOVIĆ, M.; GRDIŠA, M.; HRŽENJAK, T.M. Glycolipoprotein G-90 obtained from the earthworm Eisenia foetida exerts antibacterial activity. Veterinarski Arhiv, v.75, p.119-128, 2005.

POURHOSSEIN, Z.; QOTBI, A.A.A.; SEIDAVI, A.; LAUDADIO, V.; CENTODUCATI, G.; TUFARELLI, V. Effect of different levels of dietary sweet orange (Citrus sinensis) peel extract on humoral immune system responses in broiler chickens. Animal Science Journal, v.86, p.105-110, 2015. DOI: https://doi.org/10.1111/asj.12250.

PRAYOGI, H.S. The effect of earthworm meal supplementation in the diet on quail's growth performance in attempt to replace the usage of fish meal. International Journal of Poultry Science, v.10, p.804-806, 2011. DOI: https://doi.org/10.3923/ ijps.2011.804.806.

REZAEIPOUR, V.; NEJAD, O.A.; MIRI, H.Y. Growth performance, blood metabolites and jejunum morphology of broiler chickens fed diets containing earthworm (Eisenia foetida) meal as a source of protein. International Journal of Advanced Biological and Biomedical Research, v.2, p.2483-2494, 2014.

RODRIGUEZ-CAMPOS, J.; DENDOOVEN, L.; ALVAREZBERNAL, D.; CONTRERAS-RAMOS, S.M. Potential of earthworms to accelerate removal of organic contaminants from soil: a review. Applied Soil Ecology, v.79, p.10-25, 2014. DOI: https://doi.org/10.1016/j.apsoil.2014.02.010.

SON, J.-H. The study on treatment of poultry waste by earthworms, and the effect of feeding earthworms meal on the performance of broilers and laying hens, and safety of meat and egg. Korean Journal of Organic Agriculture, v.17, p.63-82, 2009.

STRUTI, D.; BOARU, A.; MIERLIȚĂ, D.; GEORGESCU, B. Studies regarding the effects of the redworm meal utilization as a protein substitute in Japanese quail diets. Advances in Agriculture \& Botanics, v.10, p.105-113, 2018.

SUTTON, C.D.; MUIR, W.M.; MITCHELL JR, G.E. Cholesterol metabolism in the laying hen as influenced by dietary cholesterol, caloric intake, and genotype. Poultry Science, v.63, p.972-980, 1984. DOI: https://doi.org/10.3382/ps.0630972.

ZANG, Y.T.; BING, S.; ZHANG, Y.Z.; SHENG, X.W.; SHU, D.Q. Effects of dietary supplementation with earthworm powder on production performance, blood characteristics, and heavy metal residues of broiler pullets. Journal of Applied Poultry Research, v.27, p.609-615, 2018. DOI: https://doi.org/10.3382/japr/pfy024. 